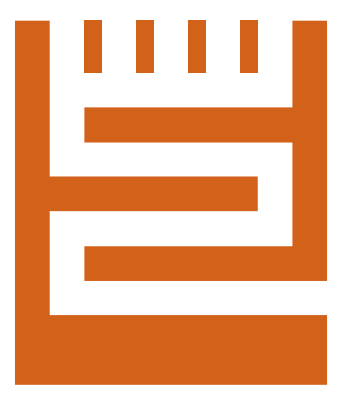

\title{
Wanting to Be Third on Your Block
}

Elaine Heumann Gurian Senior Museum Consultant 


\section{幽MUSEUM STUDIES}

Museum Studies Program

Charles H. Sawyer Center for Museum Studies

University of Michigan Museum of Art

525 South State Street

Ann Arbor, MI 48109-1354

Office phone: 734-936-6678

Fax: 734-786-0064

www.ummsp.lsa.umich.edu

ummsp@umich.edu

(C) 2010 University of Michigan

All rights reserved

The University of Michigan Museum Studies Program's series of "Working Papers in Museum Studies" presents emerging research from a variety of disciplinary perspectives, all focused on the multiple concerns of the modern museum and heritage studies field. Contributions from scholars, members of the museum profession and graduate students are represented. Many of these papers have their origins in public presentations made under the auspices of the Museum Studies Program. We gratefully thank the authors published herein for their participation.

Much of this paper was written specifically for the 2009 Michigan Museum Association Annual Meeting (Ann Arbor), but it also contains some sections from two papers soon to be published elsewhere: "The Museum as Soup Kitchen" [Curator, the Museum Journal 53 (1) 2010: 71-85] and "Curator: From Soloist to Impresario," soon to be published in a volume edited by Fiona Cameron and Lynda Kelly in Australia. For nearly 40 years, Elaine Heumann Gurian has engaged the world's museums in her various roles as consultant, educator, and visionary. She has visited the University of Michigan on several occasions; in 2007 she served as the Museum Studies Program's Visiting Scholar.

egurian@egurian.com 


\section{Wanting to Be Third on Your Block}

\section{Elaine Heumann Gurian \\ Senior Museum Consultant}

\section{History teaches us that men and nations behave wisely once they have exhausted all other alternatives.}

Abba Eban (Speech in London, 1970)

It is unrealistic to expect any major museum to venture out on the limb alone.

Peter Linnet (Curator, the Museum Journal, 2009)

"Why are many museums resistant to change?"1 "When some museum directors insist on change why are museum personnel so expert at thwarting and avoiding it?" I have been pondering these questions for a long while. Writers have considered the causes and prevention of staff resistance in the face of proposed change in management and museum literature. ${ }^{2}$ Some writers suggest that in order to be successful the process of intentional change must be transparent and honorable or the consequent behavior of staff will be resistant and potentially disruptive. This applies regardless of the kind of institution or job one is in. I will not take up this interesting literature which concentrates on ameliorating the resistance of staff but rather will address a more specific museum question, "Does this resistance have to do specifically with museum work or is it a ubiquitous response to change wherever it is found?"

In museum work we find people who have chosen their careers based on their individual philosophy, life style and interest. Their choice of profession is often very specific and has frequently been committed to from a very early age. Choosing to work in museums is certainly not based on remuneration as museum salaries are relatively low when compared to the pay similarly educated people get elsewhere. The number of museum related job openings is small and they are hotly contested because there are more people well trained for museum work than available positions. Accordingly, most museum workers are selfselected based on a mix of personal reasons, which include the role museums have played in their lives, a commitment to the nobility of the work itself, and pleasure with the position they hold in society because of it. This is especially true of those who choose employment in the specialized museum functions (curation, museum education, exhibition development and collections care, for example). The rest of the staff who have transferable skills and who come from other industries are often pleasantly surprised and choose to stay for the same reasons that others more self-consciously chose the work in the first place.

Individual museum staff members can appear to be messianic protectors of the institution, devoted to defending the essential nature of museums as they envision it. Their personal characterization of appropriate museum activity is often tied, I believe, to their view of themselves as guardians of the patrimony (physical objects) for future generations and as the benign enlightener of the current visitor. These staff envision themselves standing at the barricades fighting against those who, like me, propose change by advocating new roles for museums. These selfappointed custodians fear, sometimes quite correctly, that we seek the transformation of the institutions they love into something they will no longer recognize. They feel, in all sincerity, that their opponents are deeply misguided.

Now, in my older age, I am surprised that I sometimes thank those defenders for being resistant-a funny position for one who has advocated inclusionary change for nearly forty years. Let me confess that I find the object-based temple of the contemplative-places I have long sought to change such as the Metropolitan Museum of Art and the Louvre-divine. Equally surprising to me is that my young grandchildren are similarly entranced, no matter their age or their prior subject-matter knowledge. For all of us, going to the Met is indeed like entering the rarified thrilling world of the imagination. The journey is closer than I care to admit to the magical literature favored by these same grandchildren. Entering satisfies our perhaps secret aspirations of being super powerful, super rich and endowed with superhuman powers because, in some sense, we know those places diverge exotically from our daily environment and reflect more of the values of the people who formerly owned the objects rather than those who made them.

Allow me to name these museums as "classics." These are the object-drenched gorgeous spaces whose installations have intentionally omitted explanatory labels that might help most mere mortals. These are the places that are indeed overwhelming and memorable at the same time that they exasperate by subjecting the uninitiated to feelings of ignorance and insignificance. The indelibleness of the Metropolitan may be based in part on its indecipherability. And there are some smug minority who fear, I suggest, that the exclusive ambience might be compromised if more people understood it. Let me be clear; there are few such classic places so perfect as to be worthy of my total forgiveness. (I have not changed beyond recognition!) I would still contend that most classic museums do not reach the Met's level of delightful astonishment; instead they often evoke mystification and ultimately boredom and frustration in their visitors.

In contradistinction, there are the "inclusionist museums" 
with whom I proudly associate myself, who are committed to inclusion and accessibility-with their insistence on multisensory information and associations with daily experience. These institutions have intentionally modified and even willfully destroyed that impenetrable atmosphere so treasured by the classicists, but they often give away magic by doing so. These institutions embrace a more egalitarian philosophy asserting that the material evidence we call collections belongs to all and that any activity that welcomes the less initiated is, by definition, for the good.

The tension between the "classicists" and the "inclusionists" has existed from almost the beginning of museums themselves and there have always been side-byside contemporaneous developments of excellence by each "team" and in every age. 3 The inclusionist museums tend to be numerically fewer and are often considered generally less powerful than their more traditional siblings. They are often found in categories (children's museums, science centers, and culturally specific museums) that the classicists might not consider "real" museums. But the influence of these inclusionist institutions is huge, because they experiment with multiple strategies of interactivity that push the boundaries of their institution and of the genre as a whole. The techniques originated by these museums are the ones that slowly make their way into the mainstream, first by imitation by other inclusionist museums and then via adoption by the more flexible members of the classic category (where the change is sometimes heralded as being revolutionary). Thereafter there is an acceptance of this selfsame technique even by the most reticent using a process that I suggest be called "wanting to be the third on your block". This comes only after many others have tried it, most especially after the supplest of the classic museums have incorporated it into their own program.

I now believe that so many museums have successfully resisted changed because they aspire to remain in the "classic" camp, most especially aligned with powerful society members and reinforced by the stereotype of museums found in movies and literature. The lack of basic change among the majority of the world's museums has, I now believe, been intentional and the resistance to change has been successful overall. Neither the majority of public nor the powerful have demanded it. Quite the contrary, the controlling stakeholders, the social elites, the political officials, and the wealthy patrons, have more often funded the "classic" institutions in preference to others available in their locale. And these stakeholders have sometimes demanded that those that behave otherwise be returned to the fold, making the offending museum an example to others about the dangers inherent in experimentation. 4

An advocacy for inclusion has remained in the province of the political left, the mostly disenfranchised cultural minorities, and the free-choice educational philosophers. These advocates usually don't have sufficient political clout to effect wholesale transformations. I would suggest that the extensive range of activities needed to achieve real and meaningful inclusion appears to overturn the definition of the institution "museum" itself and is often therefore successfully resisted. Given the current stressful world situation, and the changing demographics of America (from the predominant majority culture to a majority coalition of many minority groups), most classic museums now include at least some language of inclusion in their vision or mission statements. They have often instituted outreach departments to work with the disadvantaged. Most obviously many have created engaging and often inclusionary websites while still protecting a relatively unchanged core. Cynically, it might be suggested that such activities are instituted as an unconscious sop to external pressures so that the core can remain inviolate. The actions often remain ancillary and the strategies do not invade the central museum site.

In 2001, I wrote a paper titled "Choosing among the Options" in which I suggested that museums, taken in the aggregate, were not homogeneous. 5 The tone and direction of a museum was not, I suggested, based on the subject matter of the collections but rather on the philosophy of the director, staff and board and sometimes, but not always, expressed in the mission statement. I postulated in that paper that there are five different, though often overlapping, museum types-object-based, narrative, client-centered, community-focused and national. And users could intuit the direction of the museum if they knew the answer to two fundamental questions, "Which does the museum value more-visitors or objects?" and "Is the museum primarily an instructor to or a collaborator with its audience?" Even though most museum staff will answer that their museum values both visitors and content equally and that the institution is simultaneously a civic meeting place and a place of instruction, usually one or the other of these tendencies predominates when placed on a continuum.

For example, while object-based museums are more guided by their "stuff" and the narrative museum is more interested in the story, both are collections driven and tend to be "classic". If, on the other hand, the museum wishes to be primarily responsive to those that use it, then the museum will probably fall into the category of client-centered or community-focused even if it collects many wonderful items. These museums I would term the "inclusionists." The difference is that client-centered museums tend to think of users as individuals, small social groups or families while community-focused museum focus on a larger group defined by location, economic level, or culture. The outlier here is the fifth category, government museums, because their intention is usually not controlled by the staff but rather imposed from the outside by stakeholders, often elected officials, who feel that they speak for and represent the citizenry. 
I have found all of these to be inexact definitions, understanding that all museums are hybrids of some kind; however, it is useful to see where the emphasis is placed. Quizzing oneself about the dominant direction your museum intends to take might help you determine your place on the continuum of inclusionary to classic. It is probably unfair to think that the user-focused museum is more interested in change and experimentation than their classic sibling but I suggest that it is in the nature of the inclusionists to experiment with systems that expand the comfort zone of visitors and, in doing so, care less about formal niceties than do their classic siblings.

\section{When do museums change?}

When do museums change and what is the impetus for change? I now believe that museums transform because their directors will it. It is more personality-based than I would like. Change agent directors are the indefatigable visionaries who know how to go from idea to operation. And eventually those who join him or her share the vision and form a band of believers, a passionate coterie. The director does not have to be born into privilege to crave it nor born in privation to be concerned over it. It is, for example, a birth into wealth that brought us the unlikely Ted Kennedy, the American legislative champion for the under-privileged. Visionaries appear in both museum categories-inclusionist and classic. The difference, I would suggest, is that those who cause experimentation in more classic categories expand examples seen elsewhere but do not break the mold of their sector while the directors in visionary inclusionist museums defy the traditional boundaries. These are the "first on their block" and are often vulnerable to rejection or can survive experimentation only in a museum deemed insignificant and below the radar.

The classicist director, in proposing changes, wishes to move their institutions and their field through successive steps that can be emulated by others. They recognize a need to be incrementalists. They borrow ideas from the more experimental branches of the museum community and choose the ideas that, while not the newest, might be the most ripe for acceptance. These directors are brave but not foolhardy. They pay with their personal social capital to make such changes acceptable. It is because of their clout that these changes are eventually embraced by the other classic museums and are then seen as acceptable, traditional, and timeless. The sector forgets or intentionally does not acknowledge the originators of examples they choose.

I would say that as a political move, expanding the acceptable methodology of one's own cohort is smart. It makes the director into an acknowledged pioneer. I admire these directors because those who change the procedures of their class are insistent and valiant. But their aim is to be the second, not the first, on their block. That would, metaphorically, make those that copy these expanders the "third" on their block. We are not so surprised when we find new radical museum ideas embedded in brand new museums that have no previous history to live up to nor when we find them in consciously experimental institutions in the children's and science museum categories where it is their tradition, and almost their obligation. It is when a traditional museum morphs into a more flexible museum that we take most notice.

The new installation of the Detroit Institute of Arts, while not as radical as some would like, gets noticed because a venerable old classic museum chose new ways of doing things, deviating from its more classic peers. The DIA has violated its place in the museum world if you will. It is a turncoat from its strict constructionist past into a more inclusive present. But there are more radical museums in the world than the DIA. They have a more inclusive philosophy to begin with; the cohort who works within these museums are expected to be radical, and the pressure on them is to become the leaders of innovation. If these self-consciously experimental institutions become the second on their block, they are disappointed with themselves and consider themselves imitative. ${ }^{6}$

What are the areas of new experimentation that the "first on the block" are looking into? Let me point out five areas of change. All these areas are intertwined with and affected by multiple contemporary influences. The first is the changing technological landscape and its ramifications, especially in sharing authority with unseen visitors. The second is the economic downturn, which is causing museums to rethink their core competencies, rely more heavily on their local resources, and consider the immediate needs of their community. The third is the more widespread recognition of the importance of group gathering locations (known now as "third spaces") in community building and their relevance in making museums forums for debate. The fourth change is the emerging academic and scientific interest in the more organic, emotive and intuitive explanation for things which now need to be integrated with the previous emphasis on rational, reductionist, and mechanistic systems of explanation. This can be seen in changing scientific explanation of brain function and more permissive, less systematic, business models. And finally, the fifth change is caused by a more empowered and successful minority and immigrant community who are continuing to demand a voice in our governance, collections choices and our exhibitions. The opportunities that arise from all of these are worth watching and imagining. In this paper I have chosen to elaborate on only two: the opportunity for museums to engage more in social service given the economic turndown, and the changing nature of staff responsibilities in information control (most especially the curator) given the changing role of technology. 


\section{Social Service}

Responsiveness to community need during emergencies of all kinds (including this economic downturn), challenges us who work in and love museums and causes a clear divide between the classicists and the inclusionists. At what point do you say to yourself "Are we doing enough to help our community?" or alternatively "Is what we are doing no longer the business of museums"? Now that the economic turndown is more than a year old and showing signs of turning around, I am struck by how little museums have changed in response. It seems that most institutions have tightened their belts and held their breath rather than thinking of this as a new and more fundamental opportunity. I am not surprised, given the lack of pressure put on museums to respond. I have been eager for signs that our museums have become more responsive and timely. What I have found is, aside from becoming quickly responsive to certain high-profile deaths, nothing much has changed. Some museums are choosing closure over reshaping because I envisage they cannot foresee a future as a differently-imagined institution.

I would suggest that now might be a good time to highlight how small under-funded community-embedded museums and cultural centers that are responsive and attuned to their communities might be treated as useful models in today's climate. These little places that have always wished to emulate their larger and better-funded object-rich cousins might finally gain the spotlight when and if they choose to concentrate on current community needs and invite other organizations to share in the delivery of these services within the museum structures. What I am proposing is transforming currently marginal local institutions into dynamic and community focused "clubhouses," used for building social cohesion, and incorporating social service usually delivered elsewhere (such as job retraining, educational enhancements, and public discourse) in addition to their ongoing classicist role of collections care, interpretation and exhibitions.

Museums have two important civic assets whose combination is shared by some but few other institutions. They have specialized spaces constructed to allow strangers to safely congregate and they present three-dimensional evidence that the public find worth contemplating. At their most basic museums have:

- Clean buildings with toilets, heat, and running water

- Sufficient surveillance to offer personal safety upon entering

- Gathering spaces large enough for groups of related and unrelated people to congregate

- Sufficient building maintenance and seating to keep people covered or warm as necessary, even though capital maintenance has been deferred for decades

- And, objects, if they have them, that are interesting at least to some
In other words, museums have physical attributes that could (and in some place have) served people well during periods of crisis. Museums physically rival libraries, churches and schools as useful public gathering spaces that are seen by the public as aesthetic, trustworthy and neutral. The opportunity for social service is great and varied. Whether the museums choose to provide more of it remains to be seen. Local governments fund many group-gathering facilities. These usually include public parks and recreation areas available for use during clement weather and libraries and schools available during inclement times. In many of these same towns museums are either under-funded or not included in the budget because, in part, they are not considered as necessary or as useful as parks, libraries or schools.

Consider what a difference the rehabilitation of select local museums would make if they provided attractive and useful "free indoor public parks" for days when outdoor use is not an option. Indeed in this economic crisis the attendance at venues seen as educational and recreational is going upespecially those that provide free entrance. Libraries, for example, are seeing burgeoning use while museums in the UK that have again become free have seen their attendance rise as well. 7

\section{Curators}

On another but interrelated front, the use of the internet is inevitably changing the nature of all authoritative institutions, including museums. How museums respond to multiple sources of information found on the web and who on staff should be responsible for orchestrating it is not yet clear. The change is not merely technological but at core philosophical as well. Just as with the option of social service, the determining factor will be how directors conceive their museums' relationship to their audience and how they hope that relationship will evolve. Internet use is changing many aspects of our societyhow we educate ourselves, judge the trustworthiness of information, collectively lobby for policy reform, do our work, determine where we live and how we form real and virtual communities. People use the internet to find answers to their personal inquiries. At any time of the day or night anyone using a search engine can easily find multiple sites devoted to any topic. The located sites may be written by scholars, informed amateurs, or crackpots. The content may vary. The internet user must determine who $\mathrm{s} /$ he trusts amid all that available content. Trustworthiness and accuracy is the largest issue when trolling the web. Interestingly, it is the same issue museums must grapple with as they decide how to engage with the internet.

Some websites permit, even encourage, users to add and make changes to the information they view (Wikipedia, etc.). The browser need not be a passive recipient of text created by the originating writer/authority. And there is 
an increasing level of engagement (known as Web 2.0 or social networking) that results in groups of users bypassing authoritative control altogether and just talking to each other. In those social networking sites (i.e. Facebook, MySpace, Twitter, LinkedIn, etc.) organizations of all kinds, including museums, are now establishing their own accounts so that they might get attention. Every museum visitor carrying a cell phone or MP3 player of some sort now has, or soon will have, access to subjectmatter information not generated by the institution. The editorial control of information formerly the province of most institutions is quickly coming to an end because it is so easy to find additional or contrary views on the net in real time. Museums have created websites that contain a plethora of information and so believe they are taking advantage of the new technological possibilities. Most of this information however is written by and promulgated by the museum itself and is therefore just an extension of the museum as authority. In contradistinction to information sharing found on the web, most museum exhibitions including topic choice and breadth and depth of topic exploration currently remain in the control of the institution. In fact, deeply embedded in the classic museum's self-definition is the interconnectedness of museum generated information and the object itself.

Typically the label copy of an exhibition is a synthesis of the information gathered and represents the institution's take on the matter. Some museums have experimented with allowing (even encouraging) input from others, but this is generally reserved to specifically controlled sections of the exhibition in forms such as comment books or "talk back" walls. Even when museums use outside advisory committees who have disparate views on a topic, the museum's overall presentation is generally edited and thereby ultimately controlled by the museum itself. And this is justified by the claim that museums are trustworthy in part because the content is "accurate." Obviously the more interest there is in creating dialogue with the audience, and the more multi-voiced avenues are inserted within the exhibition, the wider and deeper the discussion can range. In other words "hot" topics can be presented with both more balance and more opinionated passion if there are multiple avenues of input.

When we come to museum experimenters on the one hand and resisters to change on the other, no one position has been more passionately the advocate of the orthodox than that of curator. And while there are some curators throughout the world embracing new ways of working and the new opportunities that technology affords, the museum field generally (especially its curators and academic departments focused on training curators) remains at the core philosophically unmoved by the prospect of sharing authority with others, despite their new websites and shiny new technological reference centers. For the last century the museum staff member most responsible for creating and vetting information has been the curator. By job description, curators have been the acknowledged voice of museum authority. Accordingly, curators (and the directors they work for) have a choice and an opportunity. They can decide to maintain their traditional position of being the authoritative source of information or they can become more involved in the distribution of multi-voiced information originating elsewhere. They can encourage their museums to participate in the growing appetite and expectations their visitors have for intellectual interactivity or they can persuade themselves that visitors have come to the museum to benefit from its exclusive expertise. It can be argued that curators' reluctance to give up control is well grounded and is correctly part of the classicist belief in a canon of excellence. Museums are trusted, curators argue, because they have "real" objects and present "truthful" information. Yet we all know that acknowledged scholars do not always agree, and making their contrasting arguments known can only enhance understanding.

Given this fast changing technological world that is challenging authoritative institutions, museums are at a crossroad-down one path the narrow traditional role of unitary expert of civic trustworthiness, down the other the wider possibilities attendant to the role of knowledge gatherer, assembler and responder as a safe place for civic "forums." The pressure on classic museums to choose has been intensified by the availability of the web to all. Those directors who decide to try the second path are faced with a conundrum about the role of the curator. S/he can still retain traditional curators as his/her knowledge experts but in doing so the director will have to choose to assign the tasks of assembling multiple sources of information to the IT or the education department or both. Assigning knowledge accumulation to others without changing the responsibilities of the curator as resident expert will diminish the power of the curator as knowledge tsar. And, if the museum encourages levels of interactivity that bypass an institutional response and facilitates content that is person-to-person generated, should quality control and monitoring of such exchanges become part of the curator's job as well?

It is answers to these and similar questions that will determine the future job descriptions and relationships among, the curator, the educator and the information technologist. These are not merely administrative niceties. How these issues are resolved will go to the heart of the museum's philosophy-how it regards its role as trusted authority and how it defines its interaction with its audiences. The classicist conjoining of object and information may be severed, it is certainly under strain. And, if the profession of curators collectively decides to embrace the new role of the knowledge gatherers and distributors, then the curriculum of the graduate school and in-service training programs will need to be radically changed to reflect this new thinking. I am suggesting that 
there have always been two streams of basic museum philosophy: one that focuses on the needs of the actual and potential audience and one that focuses on the transmission of knowledge. In both cases the museums in question use three-dimensional materials as the fulcrum around which they work. I suppose encouraging the objectcentered museum to become more welcoming in their approach, more diversified in their collecting, more broadly representative in their labels, and more interested in dialogue in their programming might be seen as exemplary progress. They have a model in the DIA and others and so could comfortably be the "third on their block" if they do so. The inclusionists continue to experiment, welcome as many as possible, and remain often fiscally fragile and difficult to explain to the powerful.

One might say that we are at the traditional impasse. I do not know who will choose to tackle these new issues in the immediate future but I remain impressed by those who self-select as the originators of change-the first on their block-as well as those directors who violate their class and are brave enough to be the second.

\section{Notes}

1 I use the word "museums" to apply to all kinds of public charitable institutions that use threedimensional objects (real or specifically created) as their educational and display medium. This includes, but is not limited to zoos, aquaria, art galleries, historic houses, nature centers, botanic gardens, children's museums, science centers, and visitor centers.

2 Search for "change management" in www.amazon. com and a dozen or more books incorporating that term in their title come up, written between 1998 and 2005 .

3 See Hudson, Kenneth, Museums of Influence, Cambridge University Press (1987) and Alexander, Edward, Museums in Motion: An Introduction to the History and Functions of Museums (1979).

4 Both the National Museum of Australia and Te Papa, the National Museum of New Zealand opened to critical inclusionist success only to have the prevailing government organize the removal of their directors and a replacement of their adventurous exhibitions by more traditional ones.

5 Gurian, Elaine Heumann (2002), "Choosing Among the Options: An Opinion about Museum Definitions." Curator, the Museum Journal 45 (2): 75-88.

6 Having never been there I hesitate to suggest that the City Museum in St. Louis would fit into that category as would the Exploratorium when it was conceived by Frank Oppenheim. I would be delighted to receive suggestions for more at egurian@egurian. com.

7 For example, see http://new.wkzo.com/news/ articles/2009/sep/30/air-zoo-attendance-figuressoar/ where the Kalamazoo Zoo's attendance tripled and they had decided to extend the free offer with charging for select experiences. 